\title{
Study Potency Investment Mining Sand In North Luwu Regency
}

\author{
${ }^{1}$ Indrianty Sudirman, ${ }^{2}$ Mursalim Nohong, ${ }^{3}$ Muhammad Darwis, ${ }^{4}$ Muhammad Erik \\ Kurniawan, ${ }^{5}$ Wahyu Hidayat, ${ }^{6}$ Bambang Irawan, ${ }^{7}$ Rahmawati. \\ 1,2,3,4,5Institute for Research and Community Service (LP2M) Hasanuddin University. Street Perintis Kemerdekaan KM. 10 Kampus Unhas \\ Tamalanrea, Makassar. \\ 6,7Regional Research and Development Agency (BALITBANGDA) North Luwu Regency Street Simpurusiang No. 27 Masamba
}

Received date: 10 January 2018, Accepted date: 28 March 2018, Online date: 4 April 2018

\author{
Address For Correspondence: \\ Indrianty Sudirman,Institute for Research and Community Service (LP2M) Hasanuddin University. Street Perintis Kemerdekaan KM. \\ 10 Kampus Unhas Tamalanrea, Makassar.
}

Copyright ( 2018 by authors and American-Eurasian Network for Scientific Information.

This work is licensed under the Creative Commons Attribution International License (CC BY).

http://creativecommons.org/licenses/by/4.0/

\section{()) Open Access}

\begin{abstract}
The sand mining study discusses the economic potential of the mine point, the impact of social damage on the community, and the policy on the implementation of sand mining investment by regional company/regional owned enterprises. The study was conducted in North Luwu Regency South Sulawesi Province from April to July 2017. Data analysis used benefit cost analysis, Analytical Hierarcy Process (AHP), and SWOT analysis. The assessment results show that North Luwu Regency has 149 potential sand mining points in 11 rivers where the river with the largest sand mining potential is Rongkong River and Baliase River. Management scenario most feasible to be managed by regional company/regional owned enterprises is by land rent system because the result of B/C Ratio analysis gives the highest indicator value.
\end{abstract}

\section{KEY WORDS}

Sand Mining, River, Original Local Government Revenue, and Regional Company/Regional Owned Enterprises.

\section{INTRODUCTION}

Investment is one of the main drivers of the development process. Investment activities have broad effects such as increased employment, increased value added, and increased sources of financing for government spending. As an autonomy regional, the district/city government is required to be able to manage its own household in accordance with its authority[1]. By that, the availability of absolute revenue sources to be extracted so that local governments are not entirely dependent on the central government in the form of balancing fund transfers.

In order to synergize the improvement of regional economic growth that is sustained by increasing regional investment. The multi-aspect development of the agrosocial environment of rural territories assumes revealing differences in the level of availability of investment resources [2]. North Luwu Regency Government has prepared several efforts to encourage the increasing number of investors who invest their capital such as regulation, infrastructure, conducive security climate.

North Luwu Regency with all the potential of natural resources owned, among other large and small rivers, should be able to capture these opportunities. Potentials that can be utilized from these natural resources are the presence of materials and materials that exist on the surface such as various types of rock and sand that are beneficial to the community. Therefore, in order to obtain a strong reference in making a sand mining investment management policy required a potential assessment of the object. Data mining is the process of analyzing data from unusual aspects and abbreviation it into useful information. Information that can be used to increase revenue, cut costs, or both [3]. 
According to [4], one of the targets set is the management of sand mining by regional company/regional owned enterprises. The policy is expected to be realized with the management of sand mines to increase revenue sources of North Luwu regency in order to increase autonomy and autonomy capability.

Mining activities can create the risk of fatal ecological damage. It can not be separated from the various complex processes that must be passed in mining activities, such as how mining techniques are done, how to manage and process the mining products that have been obtained, which will ultimately affect the ecosystem in and around the mining site.

In addition, social impacts can also be seen, especially between immigrant communities and local communities. There are many factors that influence it, among them the competition for minimal job opportunities, and also local workers who majority only work as miners, while many migrants who have a better position [5].

Based on these explanations, it can be seen in macro the impacts are very diverse, including the ecological, social and economic impacts, which are on the dimensions of government actors, private and of course the community. This if continuously allowed to create a more crucial problem and certainly will lead people to a serious ecological crisis.

The objectives of this assessment are to (1) identify potential economic potentials of the mine so that more comprehensive, valid and objective investment scenarios can be obtained, (2) to identify potential social damage impacts of sand mining management for the community, and (3) to formulate the policy design that will be applied in the management of sand mining investment by Regional Company/Regional Owned Enterprises.

\section{Research Methods:}

The research was conducted in North Luwu Regency of South Sulawesi Province from April to July 2017. Data collection was done by using two stages: First phase, survey activity to determine potential mining point. This stage is carried out by observation as well as field observation about the condition of existing mining potential. In the second phase, first hand sources are conducted at various sources through Focus Group Discussion (FGD) activities, among others with related institutions / agencies, economic actors, community leaders and decision makers in the local government structure of Luwu Regency North at various levels. Interviews were conducted to find out the aspirations and needs of the community against the potential investment of sand mining. Required information such as; function and role of each stakeholder in the sand mine, the institutional form required for the sand mining strategy, model and form of cooperation among actors / actors in the management of sand mining investment, and sand mining management policy. Then the data obtained is analyzed by using a set of analytical tools that is benefit cost analysis, Analytical Hierarcy Process (AHP), and SWOT Analysis.

\section{RESULTS AND DISCUSSION}

A. Potential of Sand Mine Point in North Luwu Regency:

River sediment potential other than as a natural wealth that can be utilized as well as a threat, because it can lead to flooding with the rise of water in some rivers, especially rivers that empties into the Gulf of Bone. The potential of the sand mining sector is very large in Luwu Utara District, as evidenced by the large potential of mining dots. Sand is a mineral that is widely used as a mixture of cement, for building materials [6].The potential of sand mining is found in eleven rivers in North Luwu Utara Regency [7]. Of the eleven rivers there are 149 mine points with total production volume of $15.263 .922,78 \mathrm{M}^{3}$ with a value of 1.526.392.277.791 rupiah (Rp).

Sand is one of excavation material that is not included in strategic and vital dig. This is due to the market from this $\mathrm{C}$ quarry mining does not require international market as well as petroleum and coal. In addition to sand, limestone and marble are also not included in the strategic industry. However sand is one of the building materials that are needed by the community.

The evidence of the dependence of development on nature can be seen from the use of natural resources, especially sand mining which is one of the basic materials in building the building. Sand exploitation activities is one of the supporting sectors of the physical, economic and social development. The need for sand mining will continue to increase as the development of various physical facilities and infrastructure.

This opportunity can be captured by Regional Company/Regional Owned Enterprises in North Luwu Regency to manage the sand mining business that has huge potential both in terms of volume and from the value of the rupiah generated. From eleven rivers, it was identified that the Rongkong River and the Baliase River which have large sand mining potential.

The potential of sand found in Rongkong River is 19 mines with total production volume 3.522.272,49 $\mathrm{M}^{3}$ with a value of 352.227.248.708 rupiah. While the potential of sand found in the River Baliase there are 45 points of mine with a total production volume of $6.723 .033,37 \mathrm{M}^{3}$ with a value of 672.303 .336 .710 rupiah. 
Based on the identification of the river that has the largest sand mining potential of Rongkong River and the Baliase River so that the location of the sand mining terminal is located in Baebunta District. Selection of sand mining terminal location in Baebunta District is based on its location in the middle of both rivers and is a district adjacent to District of Masamba as the Capital of North Luwu Regency.

B. Comparative Model of Sand Mine Management by Regional Company/Regional Owned Enterprises in North Luwu Regency:

Comparison of each form of sand mining practices that can be done by Regional Company/Regional Owned Enterprises Table1.

Table 1: Comparison of Results of Eligibility Feasibility Calculator (B/C ratio)

\begin{tabular}{|c|c|c|c|c|c|c|}
\hline \multirow[b]{2}{*}{ Number } & \multirow[b]{2}{*}{ Form of management } & \multicolumn{4}{|c|}{ Indicators and Values } & \multirow[b]{2}{*}{ Information } \\
\hline & & PP & NPV (Rupiah) & $\operatorname{IRR}(\%)$ & $\begin{array}{ll}\mathrm{B} / \mathrm{C} & \text { ratio } \\
(\%) & \end{array}$ & \\
\hline 1. & $\begin{array}{l}\text { Everything is owned by } \\
\text { regional company }\end{array}$ & $\begin{array}{l}2 \text { year } 6 \\
\text { month }\end{array}$ & $554,464,337$ & Greater than $10 \%$ & 1,30 & Well worth it \\
\hline 2. & Rent the land & $\begin{array}{l}6 \text { year } 5 \\
\text { month }\end{array}$ & $3,813,554,981$ & Greater than $10 \%$ & 1,84 & Well worth it \\
\hline 3. & Everything is rented & $\begin{array}{l}2 \text { year } 7 \\
\text { month }\end{array}$ & $1,912,192,173$ & Greater than $10 \%$ & 1,30 & Well worth it \\
\hline
\end{tabular}

Information:

$\mathrm{PP} \quad=$ Payback Period

NPV $\quad=$ Net Present Value

IRR = Internal Rate of Return

$\mathrm{B} / \mathrm{C}$ Ratio = Benefit Cost Ratio

Based on the data in Table 1, it appears that all three types or forms of sand mining management in North Luwu Regency are feasible to be developed because they have the value of each optimal indicator. When comparing the three forms of management, the land rent system is most feasible to be managed or developed because it provides the highest indicator value. In addition, the land lease system also has the potential to provide the greatest non-economic benefits as both business actors and landowners will have economic and noneconomic benefits. Similarly, the number of labor involved is 8 (eight) people.

Development of management between the regional company with the private sector can be done by prioritizing proportional aspects in terms of investment, business operations and distribution of profits obtained[8]. The division of the workload can be in the form of regional company managing the mining until the collection and distribution or marketing done by private parties or it could be otherwise.

Other forms of cooperation that need to be developed to enhance the role of business entities in the community such as Village Owned Enterprises (BUMDes) and Regional Owned Enterprises (BUMDa), then the cooperation pattern developed is:

1. Sand from the original source (Rongkong River and Baliase) is collected at the storage terminal to be managed by BUMDes. This model provides an opportunity to all existing BUMDes in each village to participate and play an active role in the activity. In the long run, BUMDes can be one of the sources of local revenue.

2. BUMDes markets sand directly from the terminal to the sand mining terminal in Baebunta managed by BUMDa.

3. With the pattern of cooperation like this, will accelerate the absorption of labor in the community so that it provides benefits to the district government in the implementation of programs and activities, especially related to the absorption of labor and poverty alleviation.

C. Ecological, Social, and Economic Impacts of Sand Mining Activities in North Luwu Regency:

Negative impacts of the ecology of sand mining in Luwu Utara District: (1) The occurrence of environmental pollution and contamination of ecosystems that negatively impact human health and other living things such as deteriorating water quality, especially water flowing through rivers. In addition to being can not be consumed, the water also causes the emergence of sand deposits that threaten the livelihoods of citizens who raise fish and farmers. The pollution of the environment by heavy metals is a widespread problem all over the world. The contamination of the ecosystem by these potentially harmful elements whenever the exceeded their required threshold limits have negative effects on human health and all biota [9]; (2) Vulnerabilities to natural disasters such as landslides and floods are increasingly threatening the community. Depreciation of the size of the river that passes through most residential areas causes more frequent flooding events when large rain falls. State of the environment is critical in developing countries. In the decades after World War II, economic and political decisions of governments in developing economies, particularly industrializing economies were not focused on environmental considerations and management. In other words, governments in developing countries had poor performance to play their role as the providers of public goods, and have failed to compensate for 
themarket failure, especially attention to the environmental protection and the prevention and pollution of the environment. The state of the environment (environmental quality and the level of destruction and pollution) is the outcome of interaction and effect of decisions, interests and actions of the actors, including governments, businesses, and economic agents, environmental non-governmental organizations (NGOs), green parties and the public masses (the poor, women, peasants, etc.) and scientific authorities (the scientific communities) the national and international levels [10].

Social impact is also a very sensitive aspect if it is associated with the existence of sand mining. The polarization of the community agrees and disagrees with sand mining activities, leading to conflicts between the public and the private sector, the government or even the community itself.

Negative impact of sand mining in North Luwu Regency is the community claimed that the presence of sand mining has seized the rights and paid no attention to the public interest. Although there is compensation such as sand for mosque construction or other social activities, for the community it does not mean anything because it destroys a healthy environment and clean water.Water resources are precious resources. As such, public and decision makers urge water resources engineers and researchers to manage these resources sustainably. Limited water resources with increasing rate of population represent major challenges to water resources management in Egypt [11].

Negative impacts of the sand mining economy in North Luwu Regency: (1) The presence of sand mining in the end does not significantly affect the level of income of the community. Only a few communities work in the sand mines, and in fact are also unable to provide justice and economic improvements in society; (2) The employment opportunities in the mining sector are minimal, even the work of this sector is only open to the work of miners and truck drivers. In the end this is also one of the factors causing people to prefer to work in the non-mining sector.

Behind the negative impacts, but there are also positive impacts felt by the community and government. Although positive impacts are not very visible, but here are some positive impacts of sand mining in North Luwu Regency: (1) The existence of sand mining indirectly opens new business opportunities. This is particularly used by communities living near mine sites; (2) The existence of material assistance from the mining sector for development activities and social activities of the community. Though not well responded to by all citizens, the assistance provided by the mining side has at least contributed to building roads even to other village facilities; (3) Can reduce the siltation of the river so as to prevent / reduce the risk of flooding due to river water flows.

\section{Strategy and Policy on Investment of Sand Mine by Regional Company in Luwu Utara Regency:}

Development strategies and policies in the sand mining sector are as follows: (a) Strengthening the role of regional company; (b) Establishment of a sand distribution center/sand mining terminal at several strategic locations; (c) Localize trade through the Sand Terminal; (d) expansion of marketing area; (e) Implementing socialization and extension activities on environmental understanding of the communities in the watershed; (f) Carry out extension activities and plant management practices for erosion control; (g) Provision of technical assistance to sand mining business actors; (h) Provision of accessible and accurate sand mining information online; (i) Enhanced supervision and control functions; (j) Increased community engagement; (k) Build a partnership between regional company and sand mining business actors located in North Luwu Regency; (1) Improving the quality of road access; (m) Implement soil conservation and crop management activities for erosion control in watershed and coastal/downstream areas.

\section{Conclusion:}

Based on the analysis and discussion, it can be concluded as follows:

1. North Luwu Regency has as much sand mining potential $15.263 .922,78 \mathrm{~m}^{3}$ or worth 1.526.392.277.791,- rupiahassuming price 100.000 ,- rupiah $/ \mathrm{m}^{3}$, the potential is entirely within the broad body of the river $1.526,39 \mathrm{Ha}$ and average depth $1 \mathrm{~m}$ which are spread over 149 potential points of sand mining in 11 existing rivers.

2. Of the 11 river that ditvertarisasi, river that has the largest potential of sand mining is Rongkong River $\left(3.522 .272,49 \mathrm{~m}^{3}\right)$ and Baliase River $\left(6.723 .033,37 \mathrm{~m}^{3}\right)$.

3. From the three scenarios of sand mining management that can be managed by regional company/regional owned enterprises most feasible to be managed by regional company/regional owned enterprises is Second Scenario with land rent system because the result of B/C Ratio analysis gives the highest indicator value.

4. Management of sand mining potential by regional company/regional owned enterprises is reinforced by: (a) Construction of sand terminals at several strategic locations; (b) Website creation and e-commerce as a form of promotion, purchase, sale, marketing of sand through electronic systems; (c) Facilitating partnerships between communities of sand mining actors through sand mining terminal containers managed by regional company/regional owned enterprises; (d) Establishment of associations or organizations that accommodate sand 
mining actors belonging to regional company/regional owned enterprises groups; and (e) Synergy of crosssector programs through integrated programs between related agencies and regional company/regional owned enterprises and across regions through inter-regional cooperation.

\section{REFERENCES}

[1] Law Number 23 of 2014 on Regional Government.

[2] Viktorovna, E.C.O., T.M. Nikolaevna, G.S. Valerievna, G.V. Samvelovna, D.R. Viktorovich, 2014. Evaluation of Investment Activity of Rural Territory of the South of Russia. American-Eurasian Journal of Sustainable Agriculture. ISSN: 1995-0748, 2014 June, 8(9): Pages (7-10). Published by AENSI Publication.

[3] Rajesh, P and M. Karthikeyan, 2017. A Comparative Study of Data Mining Algorithms for Decision Tree Approaches using WEKA Tool. Advances in Natural and Applied Sciences. ISSN: 1995-0772, EISSN: 1998-1090, 2017 July, 11(9): 230-241. Published by AENSI Publication.

[4] Regional Development Planning Board of North Luwu Regency, 2016. Document of Regional Medium Term Development Plan (RPJMD) Year 2016-2021 North Luwu Regency. Cooperation Between Regional Development Planning Board (BAPPEDA) North Luwu Regency with Institute for Research and Community Service (LP2M) Hasanuddin University.

[5] Sulton, A., 2011. Impact of Mining Activities of Group C Minerals on the Living Conditions of Villagers. Essay. Bogor: Bogor Agricultural University.

[6] Environmental Office of Luwu Utara Regency, 2017. Masamba.

[7] Central Bureau of Statistics of Luwu Utara Regency, 2016. North Luwu in figures. Masamba (ID): BPS.

[8] Sudirman, I., M. Nohong, M. Darwis, M.E. Kurniawan, W. Hidayat, 2017. Document Study of Regional Revenue Sources in North Luwu Regency. Cooperation Between Regional Research and Development Agency (BALITBANGDA) North Luwu Regency with Institute for Research and Community Service (LP2M) Hasanuddin University.

[9] Obasi, N.A., S.E. Obasi, S.O. Elom, K.M. Kalu, C. Aloke, I.O. Igwenyi, C.C. Isienyi and J.C. Attamah. 2017. Health Risk Assessment of Heavy Metals In Ameri Lead-Zinc Mining Community Via Consumption of Cassava (Manihot esculenta Cruz) In Ikwo L.G.A., Ebonyi State, Nigeria. American-Eurasian Journal of Sustainable Agriculture. ISSN: 1995-0748, EISSN: 1998-1074 2017, 11(6): 22-30. Published by AENSI Publication.

[10] Shahriary, G., 2015. The Role of The Political Economy of The Environment in The Development of Globalization and Its Effect on The Environment in Developing Countries. American-Eurasian Journal of Sustainable Agriculture. ISSN: 1995-0748, EISSN: 1998-1074 2015, 9(5): 70-77. Published by AENSI Publication.

[11] Gammal, H.A.A.E., 2016. Water Quality Interventions Case Study: El-Salam Canal Area. Advances in Environmental Biology. ISSN: 1995-0756, EISSN: 1998-1066, 10(3): 35-44. Published by AENSI Publication. 